\title{
HAK MILIK INTELEKTUAL DAN PUTUSAN-PUTUSAN PENGADILAN*
}

\author{
Erman Rajagukguk ${ }^{1}$ \\ Permalink: https://www.academia.edu/9963829
}

\begin{abstract}
Intellectual Property Rights and Court Verdicts. Imitating Property rights of others, without his approval is forbidden, because the act is equal to stealing. Adherents of Utilitarianism, Jeremy Bentham stated that the Intellectual Property Rights has economic value. The owner has spent effort and money to find or create something. It is inappropriate to use it without consent of the owner, because it may cause due to people no longer willing to try to find or create something.
\end{abstract}

Keywords: Intellectual Property Rights, Courts Verdicts

\begin{abstract}
Abstrak: Hak Milik Intelektual dan Putusan-Putusan Pengadilan. Meniru Hak Milik Intelektual orang lain tanpa persetujuannya adalah perbuatan terlarang, karena perbuatan tersebut sama dengan mencuri. Penganut ajaran Utilitarianism, Jeremy Bentham menyatakan bahwa Hak Milik Intelektual memiliki nilai ekonomi. Pemiliknya telah mengeluarkan tenaga dan biaya untuk menemukan atau mencipta sesuatu. Adalah tidak pantas untuk memakainya tanpa persetujuan pemiliknya, karena hal itu dapat menimbulkan akibat orang tidak mau lagi berusaha menemukan atau menciptakan sesuatu.
\end{abstract}

Kata Kunci: Hak Milik Intelektual, Putusan-Putusan, Pengadilan

Naskah diterima tanggal: 20 Maret 2014, direvisi: 27 Mei 2014, disetujui untuk terbit: 10 Juni 2014.

${ }^{1}$ Fakultas Hukum Universitas Al-Azhar Indonesia (UAI) Jakarta. Jl. Sisingamangaraja Kebayoran Baru Jakarta. E-mail: erman.rajagukguk@yahoo.com. 


\section{Pendahuluan}

Indonesia sebagai anggota WTO/GATTs harus memiliki UndangUndang Hak Milik Intelektual dalam hubungannya dengan perdagangan internasional. ${ }^{2}$ Paling sedikit ada tujuh macam Hak Milik Intelektual yang sudah dituangkan dalam Undang-Undang, ada yang sudah lama ada, ada yang baru saja diatur dengan Undang-Undang untuk memenuhi kewajiban Indonesia sebagai anggota organisasi perdagangan dunia. Ketujuh macam Undang-Undang tersebut adalah: 1). Undang-Undang No. 29 Tahun 2000 tentang Perlindungan Varietas Tanaman. 2). Undang-Undang No. 30 Tahun 2000 tentang Rahasia Dagang. 3 ). Undang-Undang No. 31 Tahun 2000 tentang Desain Industri. 4). Undang-Undang No. 32 Tahun 2000 tentang Desain Tata Letak Sirkuit Terpadu. 5). Undang-Undang No. 14 Tahun 2001 tentang Paten. 6). Undang-Undang No. 15 Tahun 2001 tentang Merek. 7). Undang-Undang No. 19 Tahun 2002 tentang Hak Cipta.

Teori Hukum Alam menyatakan bahwa jangan meniru Hak Milik Intelektual orang lain tanpa persetujuannya, karena perbuatan tersebut sama dengan mencuri, sesuatu yang terlarang. Sementara itu penganut ajaran Utilitarianism yang tokohnya adalah Jeremy Bentham menyatakan bahwa Hak Milik Intelektual itu memiliki nilai ekonomi. Pemiliknya telah mengeluarkan tenaga dan biaya untuk menemukan atau mencipta sesuatu. Adalah tidak pantas untuk memakainya tanpa persetujuan pemiliknya, karena hal itu dapat menimbulkan akibat orang tidak mau lagi berusaha menemukan atau menciptakan sesuatu. Pihak yang mau menggunakan Hak Milik Intelektual tersebut harus mengembalikan biaya-biaya yang telah dikeluarkan untuk menemukan atau menciptakannya.

Perdagangan internasional banyak bersandar kepada nilai ekonomi dari suatu Hak Milik Intelektual. Alih teknologi dari negara maju kepada negara berkembang hanya dapat berlangsung bila negara-negara berkembang menghormati Hak Milik Intelektual dari negara-negara maju.

\section{Transformasi Hukum Di Bidang Hak Milik Intelektual}

Negara-negara berkembang, termasuk Indonesia juga melakukan transformasi hukum mengenai Hak Milik Intelektual dari negara-negara maju yang sudah lebih dulu mengaturnya dalam Undang-Undang mereka. Itulah yang menyebabkan Hukum Hak Milik Intelektual sama tetapi kadang-kadang tidak serupa di berbagai negara.

Transformasi Hukum Hak Milik Intelektual dimungkinkan karena bidang hukum ini termasuk bidang hukum yang netral, artinya bidang hukum yang tidak terkait dengan agama atau adat masyarakat, seperti Hukum Perkawinan atau Hukum Waris. Indonesia pasti tidak dapat menerima Hukum Perkawinan yang memperbolehkan perkawinan pasangan yang sama jenis atau perkawinan incest, seperti yang telah ada di Negara-Negara Barat.

${ }^{2}$ Undang-Undang No. 7 Tahun 1994 tentang Ratifikasi Agreement Establishing the World Trade Organization. 
Pelanggaran terhadap Hak Milik Intelektual sejak lama ada di Indonesia, terutama pada merek dagang dan merek barang. Bahkan pada daerah tertentu hal ini berlangsung secara terbuka, umpamanya, di daerah Tanggulangin (Sidoarjo, Jawa Timur), Gadok dekat Bogor, dan Bali. Pemerintah mengalami masalah ini, karena industri rumah tangga tersebut menampung banyak tenaga kerja. Hal ini terjadi juga di Cina, Thailand, dan negara-negara berkembang lainnya. Salah satu cara untuk mengatasi masalah ini adalah dengan memberikan persetujuan (lisensi) kepada pengusaha-pengusaha lokal untuk memakai merek tersebut, tentu dengan pembayaran royalti.

\section{Peranan Putusan Hakim}

Peraturan perundang-undangan di bidang Hak Milik Intelektual sebagiannya diadopsi dari Hukum Hak Milik Intelektual negara-negara maju seperti Undang-Undang Rahasia Dagang, Undang-Undang Desain Industri, Undang-Undang Desain Tata Letak Sirkuit Terpadu, dan Undang-Undang Perlindungan Varietas Tanaman.

Dalam beberapa hal, pengadilan juga turut mencipta hukum, karena hal-hal tertentu belum diatur dalam Undang-Undang, namun hakim harus memutus dengan adil sengketa tersebut. Hakim tidak boleh menolak memeriksa dan mengadili suatu perkara karena Undang-Undang tidak ada atau tidak jelas. Doktrin ini yang menjadi dasar hakim mencipta hukum. Misalnya dalam Tanco v. Wong A Kiong seperti berikut ini.

\section{PT. Tancho Indonesia Co. Ltd. v. Wong A Kiong, No. 521/1971 G (1972)}

Menurut Hukum Alam orang tidak boleh mencuri milik orang lain. Memalsukan merek, memakai paten orang lain tanpa izin, meniru hak cipta orang lain tanpa izin, meniru design industri pihak lain tanpa izin, menurut Hukum Alam perbuatan semua itu adalah mencuri hak milik orang lain.

Teori Hukum Alam ini pernah dipakai dalam menulis disertasi mengenai "PERLINDUNGAN MEREK" oleh H.D. Effendi Hasibuan (Jakarta: Universitas Indonesia-Fakultas Hukum-Pascasarjana, 2003).

Merek atau merek dagang (trademark) sebagai hak milik intelektual mempunyai nilai tinggi bagi pemiliknya, disamping nilai ekonomi tinggi yang terkandung dalam merek itu sendiri, setelah merek itu menjadi terkenal. Menurut teori Hukum Alam, pencipta memiliki hak moral untuk menikmati hasil ciptaannya, termasuk didalamnya keuntungan yang dihasilkan oleh keintelektualannya. ${ }^{3}$

Thomas Aquinas selaku salah seorang pelopor Hukum Alam mengatakan bahwa Hukum Alam merupakan hukum akal budi, karena itu hanya diperuntukkan bagi makhluk yang rasional. Hukum Alam lebih merupakan hukum yang rasional. Artinya, Hukum Alam adalah partisipasi

3 Rochelle Cooper Dreyfuss, Intellectual Property Law, dalam Fundamental of American Law, (New York: Oxford University Press, 1998), h. 508. 
makhluk rasional itu sendiri dalam hukum abadi. ${ }^{4}$ Selanjutnya Aquinas mengemukakan bahwa hak untuk memperoleh pemilikan adalah salah satu dari persoalan-persoalan yang diserahkan Hukum Alam kepada negara sebagai badan yang tepat untuk mengatur kehidupan sosial, artinya hak milik pribadi mempunyai fungsi sosial. ${ }^{5}$

John Locke, seorang filsuf Inggris terkemuka abad ke 18 mengatakan bahwa hak cipta memberikan hak milik eksklusif kepada seorang pencipta. Hukum Alam meminta individu untuk mengawasi hasil karyanya dan secara adil dikontribusikan kepada masyarakat. ${ }^{6}$ Kemudian Locke menyatakan bahwa atas milik pribadi bermula dari kerja manusia, dan dengan kerja inilah manusia memperbaiki dunia ini demi kehidupan yang layak tidak hanya untuk dirinya melainkan juga untuk orang lain. ${ }^{7}$

Locke memberikan solusi terhadap masalah hak-hak umum pemberian Tuhan dan pengambilan hak milik pribadi dimulai dengan asumsi bahwa, "every man has a property in his own person". Asumsi ini mengantar Locke kepada suatu pemikiran, bahwa kerja individu juga menjadi milik individu.

Untuk kebanyakan orang, teori Hukum Alam hanya semata-mata sebagai titik awal dan merupakan justifikasi terbatas untuk hukum merek. Sebagai alternatif bagi proposisi terhadap hukum alam, orang harus bergantung pada justifikasi utilitarianism dalam hal perlindungan hak-hak kekayaan tidak terwujud, ${ }^{8}$ termasuk hak kekayaan yang tersembunyi dalam hak eksklusif atas merek. Berdasarkan prinsip-prinsip ekonomi, pendekatan utilitarianism membela Undang-Undang merek sebagai suatu sistem insentif bagi pemilik dan pencipta merek.

Dalam sengketa merek yang cukup menarik dan telah menjadi yurisprudensi, yaitu meniru merek sama secara keseluruhan, untuk jenis barang yang sama. Dalam PT. Tancho Indonesia, Co. Ltd. v. Wong A Kiong, No. 521/1971 G, tanggal 6 Juli 1972.' Pengugat PT. Tancho Indonesia, Co. Ltd., adalah pemilik merek "Tancho" yang sah dan berkedudukan di Osaka Jepang. Menurut Penggugat, Tergugat, Wong A Kiong telah meniru merek Penggugat sama secara keseluruhan untuk jenis barang yang sama (kosmetik).

Dalam gugatannya, Penggugat menyatakan bahwa merek dagang "Tancho" terdiri dari dua huruf kanji dan gambar burung bangau terbang

${ }^{4}$ John Arthur dan William H. Show, ed, Reading in the Philosophy of Law, (New Jersey: Prentice Hall, Englewood Cliff, 1993, h. 73. Lihat juga Thomas Aquinas, Summa Theologiae, (London: Blackfriers, 1996), dalam Sonny Keraf, Hukum Kodrat dan Teori Hak Milik Pribadi, (Yogyakarta : Kanisius, 1997), h. 22.

${ }^{5}$ W. Friedman, Teori dan Filsafat Hukum - Telaah Kritis Atas Teori-Teori Hukum (Terjemahan Edisi Indonesia), (Jakarta : PT. Rajagrafindo Persada, 1993), h. 64.

${ }^{6}$ Craig Joice, William Patry, Marshall Leaffer dan Peter Taszi, Copyright Law Casebook Series, Forth Edition, (New York : Matthew Bender \& Company Incorporated, 1998), h. 56.

${ }^{7}$ John Locke, Summa Theologiae, (London : Blackfriers, 1996), dalam Sonny Keraf, Hukum Kodrat dan Teori Hak Milik Pribadi, (Yogyakarta : Kanisius, 1997), h. 77.

8 Peter Drahos, A Philosophy of Intellectual Property - Docke, Labor and the Intellectual Commons, (England : Darthmouth Publishing Company Limited, 1996), h. 44.

${ }^{9}$ Putusan Pengadilan Negeri Jakarta Pusat No. 521/1971 G. 
dalam lingkaran untuk barang-barang kosmetik dan telah didaftarkan sejak tahun 1961 di Philipina, Singapore, dan Hong Kong, serta pada tahun itu juga barang-barang keluaran Tancho tersebut telah dikenal di Indonesia. Untuk melancarkan perdagangan di Indonesia, Tancho, Co. Ltd. mengadakan Joint Venture dengan N.V. The City Factory, sehingga terbentuklah PT. Tancho Indonesia, Co. Ltd. (Penggugat). Kemudian, Pengugat mendaftarkan mereknya di Indonesia, tetapi secara lisan ditolak oleh Kantor Merek.

Rupanya Tergugat, Wong A Kiong telah meniru merek Penggugat sama secara keseluruhan untuk jenis barang yang sama (kosmetik), bahkan tergugat menyatakan sebagai pemakai merek Tancho pertama di Indonesia dan telah mendaftarkannya di Kantor Merek. Selain dari itu, Tergugat mencantumkan dalam label merek, seolah-olah produksi barang buatan luar negeri, padahal buatan dalam negeri.

Tergugat pada pokoknya menyangkal bahwa Penggugat sebagai pemilik dan pemakai pertama merek dagang "Tancho" di Indonesia. Sebaliknya, menurut Tergugat ia sebagai satu-satunya yang berhak dan sebagai pemilik merek dagang "Tancho" di Indonesia.

Penggugat menyatakan telah memakai merek Tancho di Indonesia sejak 1949. Menurut Penggugat, yang berhak atas merek Tancho di Philipina, Singapore, dan Hong Kong adalah Tancho, Co. Ltd. yang berkedudukan di Osaka Jepang dan bukan Tergugat. Tergugat tidak berhak sama sekali atas merek Tancho tersebut baik di Indonesia maupun diluar negeri; Penggugat menerangkan pula, bahwa pada bulan April 1969 telah datang wakil dari Tancho, Co. Ltd. Jepang untuk membeli hak Penggugat atas merek Tancho yang telah terdaftar di Kantor Merek, tetapi Penggugat menolaknya.

Pengadilan Negeri Jakarta Pusat dalam putusannya menyatakan, bahwa Tergugat Wong A Kiong adalah satu-satunya yang berhak di wilayah Indonesia karena pendaftar pertama. Atas putusan itu PT.Tancho Indonesia naik kasasi ke Mahkamah Agung. Mahkamah Agung berpendapat, antara lain, sesuai dengan maksud Undang-Undang Merek 1961 yang mengutamakan perlidungan terhadap khalayak ramai, maka perkataan "pemakai pertama di Indonesia" harus ditafsirkan sebagai "pemakai pertama di Indonesia yang jujur dan beritikad baik", sesuai dengan azas hukum bahwa perlindungan diberikan kepada orang yang beritikad baik dan tidak kepada orang yang beritikad buruk. Mahkamah Agung kemudian membatalkan putusan Pengadilan Negeri dan menyatakan Penggugat adalah pemilik dan pemakai pertama merek dagang Tancho di Indonesia.

Putusan perkara Tancho tersebut merupakan terobosan Mahkamah Agung. Menurut penulis putusan Mahkamah Agung tersebut mengikuti Hukum Alam, yaitu orang harus beritikad baik dan tidak boleh mencuri milik orang lain. Putusan Mahkamah Agung itu diikuti pembuat Undang-Undang dalam pembaharuan Undang-Undang Merek selanjutnya. 


\section{Penutup}

Kurikulum Hak Milik Intelektual ini yang terdiri dari paling sedikit 7 Undang-Undang dan peraturan-peraturan pelaksanaannya dalam bentuk Peraturan Pemerintah, Keputusan Presiden, dan Keputusan Direktur Jenderal Hak Kekayaan Intelektual Departemen Hukum dan HAM telah dapat diperoleh melalui buku-buku dan internet. Namun kuliah Hukum Hak Milik Intelektual ini perlu dilengkapi dengan putusan-putusan pengadilan, antara lain untuk melihat bagaimana peraturan perundang-undangan diterapkan dalam kasus-kasus yang nyata. Topik ini dapat menjadi topik skripsi, thesis, maupun suatu disertasi.

\section{Pustaka Acuan}

Aquinas, Thomas, Summa Theologiae, London: Blackfriers, 1996

Arthur, John, dan William H. Show, ed, Reading in the Philosophy of Law, (New Jersey: Prentice Hall, Englewood Cliff, 1993

Cooper Dreyfuss, Rochelle, Intellectual Property Law, dalam Fundamental of American Law, New York: Oxford University Press, 1998.

Drahos, Peter, A Philosophy of Intellectual Property - Docke, Labor and the Intellectual Commons, England: Darthmouth Publishing Company Limited, 1996.

Friedman, W., Teori dan Filsafat Hukum - Telaah Kritis Atas Teori-Teori Hukum (Terjemahan Edisi Indonesia), Jakarta: PT. Rajagrafindo Persada, 1993.

Joice, Craig, William Patry, Marshall Leaffer dan Peter Taszi, Copyright Law Casebook Series, Forth Edition, New York: Matthew Bender \& Company Incorporated, 1998.

Keraf, Sonny, Hukum Kodrat dan Teori Hak Milik Pribadi, Yogyakarta: Kanisius, 1997.

Locke, John, Summa Theologiae, London: Blackfriers, 1996

Putusan Pengadilan Negeri Jakarta Pusat No. 521/1971 G.

Undang-Undang No. 7 Tahun 1994 tentang Ratifikasi Agreement Establishing the World Trade Organization. 